\title{
IMPLEMENTASI DIGITAL ASSURANCE DALAM PENINGKATAN MUTU PENDIDIKAN DI SASTRA INGGRIS IAIN SURAKARTA
}

\author{
Oleh \\ Akhmad Anwar Dani ${ }^{1}$, Ari Hikmawati ${ }^{2}$, Fathan Fathan ${ }^{3}$ \\ ${ }^{123}$ IAIN Surakarta, Sukoharjo Jawa Tengah \\ 1a.anwar.d@gmail.com, ${ }^{2}$ bundakuary@ gmail.com, ${ }^{3}$ askha69@ gmail.com
}

diterima 23 Januari 2019, direvisi 19 Februari 2019, diterbitkan 28 Februari 2019

\begin{abstract}
Educational quality assurance is an important part of the education system, its function is to ensure that the education process goes according to plan and is able to achieve the goals effectively and efficiently. The implementation of Digital Assurance in the English Literature Department of Surakarta IAIN is one of the innovative steps in the quality assurance process at Surakarta IAIN. This paper will describe the transformation process that occurs in the implementation of Digital Assurance. Data obtained from interviews and documentation studies. The analysis carried out concluded that the transformation process of quality assurance based on Digital Assurance in the Department of English Literature used a Top-Down pattern. Transformation is supported by leadership factors and strong commitment, adequate human resource support and a conducive organizational ecosystem.
\end{abstract}

\section{Keywords: Quality Assurance; Digital Assurance; IAIN Surakarta}

\section{PENDAHULUAN}

Penjaminan mutu perguruan tinggi di Indonesia secara formal baru dimulai tahun 2003 dengan terbitnya pedoman penjaminan mutu perguruan tinggi. Faktor yang paling memacu gerakan penjaminan mutu adalah keharusan perguruan tinggi untuk menyelenggarakan penjaminan mutu, di samping tuntutan akuntabilitas dan kualifikasi lulusan (Mark Olssen, 2004). Penjaminan mutu di perguruan tinggi secara keseluruhan sangat penting sebab sasaran pendidikan bukan hanya untuk akademik semata, akan tetapi keseluruhan pribadi (Adina, 2007). Namun dalam sisi lain kehadirannya dapat didasari alasan lain seperti ketidakpuasan dari tenaga kependidikan dan mahasiswa serta desakan karena terbatasnya dana dan paling penting ialah tuntutan untuk melakukan pertanggung jawaban terhadap kelembagaan (Tsui, 2002).

Perguruan tinggi didorong untuk mengejar standar mutu yang lebih baik karena inovasi teknologi dan perilaku pasar pragmatis rasional. Dalam manajemen sumber daya manusia disebutkan bahwa 
setiap orang dalam sebuah organisasi berhak mengembangkan dirinya dalam rangka peningkatan dan kemajuan kariernya (Cecep, 2011). Mutu dalam lingkup pendidikan di perguruan tinggi memiliki arti bahwa fungsi, tujuan, serta standar yang ditentukan dan dijalankan di lingkup perguruan tinggi telah sesuai, memenuhi syarat, harapan, dan kepuasan stakeholder. Perguruan tinggi yang tidak berbenah akan ditinggalkan oleh stakeholders.

Penjaminan mutu merupakan suatu proses sistematis dan berkelanjutan yang bertujuan menghasilkan, meningkatkan, dan mempertahankan mutu suatu institusi sehingga kualitasnya terjamin dan diakui masyarakat. Penjaminan mutu di perguruan tinggi dilakukan untuk mengukur seberapa efektif kebijakan akademik yang diterapkan dan seberapa tinggi mutu lulusan yang dihasilkannya, selain untuk meningkatkan daya saing di antara Perguruan Tinggi, baik di dalam maupun di luar negeri. Menurut Kementrian Pendidikan Nasional, penjaminan mutu perguruan tinggi adalah proses perencanaan, pemenuhan, pengendalian, dan pengembangan standar pendidikan tinggi secara konsisten, sehingga pemangku kepentingan internal dan eksternal perguruan tinggi dapat memperoleh kepuasan atas kinerja dan keluaran perguruan tinggi (RISTEKDIKTI, 2016). Perguruan tinggi melakukan upaya peningkatan mutu pendidikan tinggi diantaranya melalui implementasi sistem penjaminan mutu internal.

Implementasi Penjaminan mutu di perguruan tinggi tidak semuanya dapat berjalan dengan baik. Berbagai masalah muncul baik dalam proses implementasi maupun sejak awal pada saat praimplementasi. Diantara masalah yang paling pokok dalam implementasi penjaminan mutu adalah tidak terciptanya budaya mutu dalam ekosistem perguruan tinggi. Tidak terciptanya budaya mutu dipicu oleh tidak adanya kesadaran mutu pada tingkatan pimpinan lembaga. Pimpinan yang tidak memiliki kesadaran mutu akan memunculkan visi dan misi yang tidak berorientasi pada peningkatan mutu. Visi dan misi turun menjadi kebijakan dan program prioritas. Program yang dikembangkan akan menciptakan ekosistem dan suasana akademik. Sehingga jika visi dan misi yang ditetapkan tidak berorientasi pada mutu maka sulit untuk dapat memunculkan ekosistem berorientasi jaminan mutu. (Suci, 2017)

Proses jaminan mutu perguruan tinggi yang baik tidak hanya terjadi pada tingkatan institut secara umum namun harus sampai pada struktur terkecil yaitu jurusan atau Jurusan. Pada tingkatan jurusan biasanya terbentuk gugus kendali mutu atau tim penjaminan mutu yang berasal dari dosen dan mahasiswa. Tugas utamanya adalah untuk melakukan kegiatan penjaminan mutu pada tingkatan jurusan. Jurusan Sastra Inggris IAIN Surakarta merupakan salah satu jurusan yang melakukan proses jaminan mutu secara terintegrasi. Proses jaminan mutunya dilaksanakan memanfaatkan teknologi informasi atau yang dikenal dengan digital assurance. Pemanfaatan digital assurance sebagai instrumen kendali mutu dikembangkan dengan asumsi dasar bahwa penggunaan infrastruktur berbasis teknologi informasi akan memudahkan proses implementasi dengan tingkat efektifitas dan efisiensi yang tinggi.(Nuraeni, 2012)

Proses implementasi jaminan mutu berbasis digital assurance di Jurusan Sastra Inggris bukanlah tanpa masalah, hambatan utama yang ditemui adalah hambatan adopsi teknologi. Beberapa dosen kesulitan untuk beradaptasi dengan teknologi baru. Selain itu ketersediaan infrastruktur akses internet menjadi salah satu hambatan. Namun dengan kepemimpinan yang kuat, komitmen untuk meningkat kualitas hambatan-hambatan tersebut dapat teratasi. Sehingga proses transformasi sistem jaminan mutu berbasis digital dapat berjalan dengan baik. Keberhasilan proses transformasi yang dilakukan jurusan Sastra Inggris dalam impelementasi jaminan mutu berbasis digital menarik untuk diteliti karena hingga saat ini belum ada jurusan lain yang dapat 
melaksanakan hal serupa di IAIN Surakarta. Perlu didalami bagaimana proses transformasi dilakukan ? Faktor apa saja yang mendukung proses transformasi ? Apa saja kendala yang dihadapi ? Bagaimana cara mengatasi kendala proses transformasi ?

Pembahasan tentang proses transformasi jaminan mutu berbasis digital di Jurusan Sastra Inggris IAIN Surakarta berbasis data-data yang didapatkan dari wawancara dan studi dokumentasi. Subjek utamanya adalah ketua jurusan, sekretaris jurusan dan beberapa dosen serta mahasiswa. Data yang didapatkan dianalisis dengan analisis deskriptif menggunakan pendekatan manajemen transformasi pendidikan sebagai unit analisisnya.

Implementasi jaminan mutu bukan hal baru dalam diskusi tentang proses pengembangan pendidikan tinggi. Beberapa isu yang sering dibahas dalam proses implementasinya adalah kebijakan penjaminan mutu (Suci, 2017)(Fitrah, Ruslan, \& Hendra, 2018), manajemen dan budaya organisasi (Willar, Linton, Kaparang, \& Kaparang, 2015) (Eko Supriyanto, 2012), pemanfaatan teknologi dalam proses jaminan mutu (Nuraeni, 2012) (Ngurah Triyana, 2017), hambatan implementasi jaminan mutu (Sulaiman \& Wibowo, 2016) (Sulaiman \& Wibowo, 2016).

Kebijakan penjaminan mutu merupakan pangkal dari implementasi jaminan mutu. Perumusan kebijakan arah pengembangan mutu seringkali tidak hanya ditentukan oleh pihak internal, seringkali pihak eksternal turut mempengaruhi kebijakan mutu. Pelibatan pihak eksternal dalam proses penyusunan kebijakan mutu dapat meningkatkan standar mutu yang ditetapkan. Hal ini terjadi jika pihak luar yang dilibatkan adalah pengguna produk yang lebih memahami kebutuhan real di lapangan. Peran pimpinan perguruan tinggi dalam penentuan kebijakan mutu cukup sentral. Pemimpin yang peduli dengan arah kebijakan mutu akan menekankan aspek profesionalitas pada saat penyusunan struktur pelaksana di bawahnya. Seringkali penentuan struktur organisasi ditetapkan berdasarkan prinsip balas budi dari pada profesionalitas dan kinerja. Hal ini berpengaruh secara signifikan terhadap jaminan mutu penyelenggaraan pendidikan.(Nuraeni, 2012)

Pemilihan SDM berbasis profesionalitas dan kinerja akan berdampak secara signifikan terhadap budaya organisasi dan iklim kinerja yang kondusif, demikian sebaliknya. Selain penciptaan budaya organisasi yang baik, pola komunikasi dan hubungan antar bagian di dalam organisasi menjadi salah satu faktor yang berperan dalam penjaminan mutu. Lalu lintas informasi yang transparan dan akuntabel dapat menjadi salah satu indikator kualitas budaya organisasi. Jaminan mutu sebagai sistem yang melekat pada organisasi bergantung pada beberapa faktor, salah satunya adalah transparansi dan akuntabilitas informasi.(Willar et al., 2015)

Penggunaan digital assurance dalam penjaminan mutu dimaksudkan untuk memudahkan pengelolaan dan akses informasi di dalam organisasi. Efektifitas dan efisiensi merupakan salah satu tujuan dari implementasi teknologi informasi dalam proses penjaminan mutu. Namun implementasi digital assurance mengalami hambatan utama dari kemampuan SDM dalam beradaptasi dengan perubahan yang cenderung lambat. Kesadaran akan pentingnya akuntabilitas dan transparansi informasi yang dapat dihadirkan dengan pemanfaatan digital assurance dapat menjadi pendorong meningkatnya akseptabilitas atas hal tersebut. Tanpa akseptabilitas terhadap teknologi yang diterapkan maka proses jaminan mutu berbasis digital assurance akan terhambat.(Basuki \& Basuki, 2004)

Akseptabilitas hanyalah salah satu masalah yang harus dihadapi dalam proses implementasi digital assurance. Masalah lain yang sering terjadi adalah keterbatasn SDM pelaksana jaminan mutu, kejenuhan auditor dalam proses jaminan mutu yang menjadi rutinitas dan stagnan. Ada pula masalah yang berasal dari sikap acuh SDM terhadap pentingnya jaminan mutu, baik pada level pimpinan maupun anggota organisasi. 
Ketidaksadaran terhadap pentingnya jaminan mutu merupakan masalah pokok yang harus dihadapi dalam proses pengembangan jaminan mutu di perguruan tinggi.(Sulaiman \& Wibowo, 2016)

Artikel ini mencoba untuk menampilkan sisi lain dari implementasi sistem jaminan mutu dengan model digital assurance, tidak hanya dari satu sudut pandang isu yang telah dibahas sebelumnya tapi dari keseluruhan aspek. Dimulai dari kebijakan mutu, budaya organisasi, pemanfaatan teknologi informasi hingga masalah-masalah yang dihadapi dalam proses implementasinya. Selain itu proses transformasi nilai-nilai jaminan mutu dari pemimpin kepada seluruh anggota organisasi menjadi salah satu fokus bahasan artikel ini.

\section{HASIL DAN PEMBAHASAN}

A. Implementasi Digital Assurance di Jurusan Sastra Inggris IAIN Surakarta

Jurusan Sastra Inggris IAIN Surakarta merupakan Jurusan yang mengimplementasikan Digital Assurance dalam proses jaminan mutu pendidikannya. Transformasi sistem jaminan mutu manual menuju Digital Assurance memerlukan waktu yang cukup lama, dalam rentang waktu 4 tahun hingga saat ini. Implementasi

Digital Assurance dilatarbelakangi oleh beberapa faktor, keterbatasan sumber daya untuk melakukan kegiatan jaminan mutu, ketersediaan dosen yang mampu mengembangkan sistem secara mandiri, Digital Assurance lebih efektif dan efisien dalam implementasinya.

Digital Assurance merupakan salah satu bagian dari digitalisasi sistem pembelajaran di jurusan Sastra Inggris. Sebelum mengimplementasikan Digital Assurance, jurusan ini telah menetapkan industri digital kreatif sebagai sektor utama yang akan menjadi garapan alumninya. Sehingga kurikulumnya diarahkan untuk dapat menopang hal tersebut. Kurikulum inti dibagi dalam 3 kategori, mata kuliah teori dasar, mata kuliah berbasis produk dan project, mata kuliah orientasi deseminasi produk digital. Implementasi kurikulum juga ditopang dengan kegiatan penelitian dan pengabdian dosen yang diarahkan ke industri digital, seperti media pembelajaran berbasis digital, game pembelajaran kreatif, evaluasi pendidikan berbasis digital.

Transformasi kurikulum yang mengarah pada industri digital tidak langsung dapat diterima oleh semua dosen dan mahasiswa. Dibutuhkan sosialisasi yang masif dan intensif baik secara formal maupun informal lewat pertemuanpertemuan rutin jurusan. Dalam salah satu pertemuan terungkap bahwa salah satu penunjang tranformasi tersebut adalah perlunya kontroling kualitas proses pembelajaran. Hal ini mendorong penggunaan Digital Assurance untuk dapat mengatasi keterbatasan SDM yang tersedia untuk melakukan kontroling. Dengan mekanisme digital, kontroling dapat dilakukan oleh ketua jurusan berbasiskan data digital yang diberikan oleh mahasiswa dan dosen dalam proses perkuliahan.

Berbasis data digital yang dimiliki, ketua jurusan dapat mengambil keputusan secara tepat, seperti saat menegur salah seorang Dosen Luar Biasa yang hingga akhir semester belum melakukan tatap muka secara lengkap. Saat ditanya, dosen yang bersangkutan mengelak dengan mengatakan bahwa telah melakukan 12 kali tatap muka. Namun saat dikomparasi dengan data kehadiran dosen yang tercatat pada sistem digital dosen tersebut tidak dapat mengelak lagi. Hal ini hanya salah satu contoh dari efektifitas dan efisiensi penggunaan Digital Assurance di jurusan Sastra Inggris.

Jurusan Sastra Inggris mengembangkan beberapa aplikasi penunjang proses digital assurance. Diantaranya adalah website jurusan (untuk informasi dan publikasi produk mahasiswa), sistem dokumentasi portofolio mahasiswa sebagai track record dalam pemilihan konsentrasi, LENS (Lecturer Evaluation by Student). Dari sekian sistem tersebut, LENS akan menjadi fokus pembahasan artikel ini.

Sistem LENS hadir sebagai solusi terhadap kesulitan pengelola jurusan, baik ketua maupun sekretaris jurusan dalam 
melakukan evaluasi kualitas perkuliahan yang dilaksanakan oleh dosen. Beberapa kasus terjadi dalam perkuliahan dan memicu pengelola jurusan untuk mencari solusinya. Diantaranya dosen tidak masuk kelas tetapi meminta mahasiswa untuk mengambil absen dan menandatangani; perkuliahan tidak di kelas yang sudah ditentukan jurusan; perkuliahan hanya dilakukan separuh waktu; jurnal mengajar yang diisi oleh dosen tidak menjamin proses belajar mengajarnya benar benar dilakukan. Masalah-masalah ini kemudian memicu dikembangkannya LENS.

Sistem LENS dikembangkan secara mandiri olah salah satu dosen Sastra Inggris. Sistem ini dibangun dengan konsep multidevice. Dapat dipasang pada smartphone android, namun juga tetap dapat diakses lewat desktop. Hal ini dimaksudkan untuk memudahkan akses bagi pengguna. LENS digunakan oleh dosen dan mahasiswa sebagai penginput datanya. Saat memulai proses pembelajaran dosen melakukan check-in secara digital lewat android ataupun desktop, perwakilan mahasiswa (ketua kelas, sekretaris dan bendahara) memvalidasi kehadiran dosen lewat aplikasi mereka. Pada akhir pembelajaran perwakilan mahasiswa mengisi form penilaian perkuliahan pada hari itu. Semua data tersimpan secara realtime di pusat data jurusan. Data ini dapat diakses kapan saja dan dari mana saja oleh ketua atau sekretaris jurusan.

Sebenarnya IAIN sendiri telah menyediakan form penilaian secara digital lewat SIAKAD, namun form tersebut hanya diisi di akhir perkuliahan dan cenderung tidak objektif, karena mahasiswa cenderung dipaksa untuk mengisi sebagai syarat untuk dapat melihat nilai akhir mereka. Selain itu, data tersebut tidak dapat diakses secara langsung oleh jurusan, hanya admin bidang akademik fakultas yang dapat mengaksesnya. Faktor ini pula yang mendorong dibangunnya LENS.

Implementasi sistem LENS diawali dengan sosialisasi di kalangan dosen. Pada proses sosialisasi beberapa dosen memberikan tanggapan yang beragam, ada yang mendukung, ada yang enggan menggunakan. Beberapa dosen menganggap seolah jurusan tidak percaya bahwa mereka telah mengajar dengan baik. Beberapa yang lain menganggap penerapan aplikasi hanya menambah beban pekerjaan saja. Menanggapi tanggapan negatif beberapa dosen, pihak jurusan mendemonstrasikan mudahnya penggunaan aplikasi LENS dan meyakinkan bahwa hal itu tidak menambah pekerjaan atau bahkan merepotkan dosen. Dari simulasi tersebut sebagian mayoritas dosen menganggap bahwa LENS berpotensi untuk digunakan.

Sosialiasi juga dilaksanakan kepada mahasiswa, dalam proses sosialisasi beberapa mahasiswa ditunjuk untuk menjadi perwakilan pada setiap kelas di setiap mata kuliah. Tugas mereka adalah memvalidasi data cekin dosen pada awal pertemuan, lalu mengisi form evaluasi kegiatan pembelajaran pada akhir perkuliahan. Beberapa minggu pasca sosialisasi dan penerapan LENS terlihat beberapa dosen masih belum menggunakan LENS dengan alasan yang beragam. Lupa cek-in dan buruknya koneksi internet adalah keluhan utama para dosen. Dari evaluasi ini kemudian jurusan membuat trobosan dengan berlangganan akses internet speedy secara mandiri untuk mengatasi keterbatasan bandwith. Sedangkan untuk mengatasi dosen yang lupa untuk cek-in, mahasiswa diminta untuk mengingatkan dosen jika lupa. Hanya masalah cadangan listrik (genset) pada saat pemadaman dilakukan oleh PLN yang tidak dapat diatasi karena keterbatasan akses dan kewenangan jurusan pada hal tersebut.

Impelementasi LENS terbukti dapat meningkatkan efektifitias dan efisiensi jaminan mutu yang berujung pada peningkatan kualitas pembelajaran. Pada evaluasi akhir semester ditemukan bahwa semua dosen telah menggunakan LENS dengan baik. Masalah-masalah yang muncul pada awal implementasi tidak lagi ditemukan pada akhir semester. Semua dosen tidak lagi menganggap LENS sebagai penghambat pembelajaran, malah sebaliknya. 


\section{B. Proses Transformasi Digital Assurance}

Proses transformasi sistem Digital Assurance yang dilakukan oleh jurusan Sastra Inggris IAIN Surakarta didukung oleh beberapa faktor, yang utama adalah unsur kepemimpinan yang kuat dan berkomitmen terhadap kendali kualitas pendidikan, ketersediaan SDM pengembang sistem, dan ekosistem organisasi yang solid.

Kepemimpinan sangat berperan dalam pencapaian tujuan lembaga atau organisasi. Kepemimpinan yang amanah dan bertanggung jawab dapat membawa lembaga atau organisasi maju dan berkembang. Kepemimpinan juga sangat erat kaitannya dengan power atau kekuasaan. Kepemimpinan yang prospektif ditentukan oleh gaya dan kinerja pemimpin dari suatu lembaga atau organisasi. Pada lembaga pendidikan, pimpinan tertinggi dijabat oleh kepala sekolah, dekan, rektor dan sebagainya. Jabatan ini memerlukan beberapa persyaratan utama yang akan mempengaruhi, mengarahkan dan memimpin lembaga atau organisasinya untuk mencapai tujuan yang telah ditetapkan.

Pemimpin yang profesional harus mempunyai kekuatan untuk memimpin bawahannya, sehingga efektif dalam pekerjaan yang diembannya. Pemimpin yang tidak efektif, tidak akan bisa mencapai tujuan lembaga atau organisasi secara baik. Salah satu indiaktornya adalah rendahnya prestasi belajar peserta didik. Selanjutnya, ditemukan kurang disiplinnya pendidik dan tenaga kependidikan di lembaga tersebut(Syafnan, 2016).

Proses transformasi dalam implementasi digital assurance di jurusan Sastra Inggris IAIN Surakarta merupakan inisiatif dari pengelola jurusan (ketua dan sekretaris) yang melihat beragam persoalan bersumber pada rendahnya kualitas jaminan mutu. Hal ini disebabkan oleh keterbatasan SDM yang melaksanakan proses jaminan mutu. Oleh karena itu, pemanfaatan teknologi dipilih untuk mengatasi masalah keterbatasan SDM pelaksana jaminan mutu jurusan.
Inisiasi digital assurance merupakan implementasi kebijakan yang diturunkan dari visi dan misi jurusan Sastra Inggris. Visi dan misi jurusan yang ditetapkan pada proses review kurikulum meniscayakan hal tersebut untuk dapat mencapai profil lulusan yang berkualitas, kreatif dan terdepan dalam implementasi digital creative. Selayaknya sebuah impian, visi menginspirasi misi yang disusun untuk mencapai impian yang ditetapkan. Semua kebijakan yang muncul dari misi harus mengarah pada tercapainya visi. Program-program disusun sebagai alat untuk melaksanakan kebijakan. Melalui berbagai program yang dijalankan terjadi internalisasi nilai yang berujung pada terbentuknya budaya organisasi.

Proses transformasi harus dimulai dari komitmen yang kuat dari pemimpin organisasi. Tanpa kepemimpinan yang kuat proses tranformasi hanya akan berhenti pada tingkatan visi dan misi. Proses breakdown visi dan misi menjadi kebijakan akan mengalami hambatan dari berbagai pihak yang merasa tidak selaras dengan kebijakan tersebut. Pada posisi ini, kepemimpinan yang kuat berperan untuk meyakinkan semua pihak bahwa kebijakan yang dibuat merupakan cara terbaik untuk mencapai visi yang disepakati bersama (Indarti, 2017).

$$
\text { Impelementasi }
$$

kebijakan membutuhkan dukungan SDM yang baik, terutama dalam implementasi sistem berbasis digital. Dibutuhkan SDM yang mampu menerjemahkan kebijakan atau program dalam bentuk produk digital. Tidak semua organisasi memiliki SDM yang mampu mengkreasi produk digital, namun hal ini bisa diatasi dengan bekerjasama dengan pihak lain yang lebih ahli. SDM tidak hanya dibutuhkan untuk mengkreasi, namun juga dalam proses sosialiasi. Dibutuhkan SDM yang mampu menjadi contoh pengguna ahli yang mampu sekaligus sebagai tutor bagi pengguna lain. Sistem peer tutor merupakan salah satu model yang paling efektif dalam proses sosialisasi aplikasi digital.

Implementasi digital assurance pada awal pelaksanaannya mendapat beberapa kendala, beberapa dosen menganggap sistem 
tersebut tidak tepat dan menambah pekerjaan; koneksi internet yang sering tidak optimal, proses adaptasi teknologi baru yang lamban pada beberapa dosen senior. Berbagai cara dilakukan untuk mengatasi kendala tersebut, sosialisasi dan komunikasi intensif merupakan yang utama. Kendala infrastruktur diselesaikan dengan penambahan fasilitas koneksi internet secara mandiri oleh jurusan pada beberapa titik penting.

Generasi milenial cenderung lebih mudah beradaptasi terhadap sebuah produk digital baru. Mereka terlatih untuk mengeksplorasi hal baru lalu menemukan dan memahami fungsi sebuah produk. Sayangnya pola ini tidak dapat diterapkan pada generasi sebelumnya. Dibutuhkan sosialisasi dan pendampingan yang lebih intensif agar produk digital dapat diterima dan digunakan oleh mereka. Dengan pendamping yang berasal dari sejawat, transfer pengetahuan tentang produk baru menjadi lebih efektif dan efisien. Pola ini digunakan oleh jurusan Sastra Inggris dalam proses pengembangan hingga sosialisasi aplikasi LENS. Aplikasi tersebut dikembangkan secara mandiri oleh salah satu dosen internal. Setelah proses uji coba yang intensif, aplikasi kemudian disosialisasikan kepada dosen dan mahasiswa sebagai pengguna. Pendampingan dosen menjadi salah satu titik krusial dalam proses sosialisasi. Karena beberapa dosen masih berasumsi bahwa produk digital sulit untuk digunakan, sehingga diperlukan pendampingan yang lebih intensif. Oleh karenanya pendampingan tidak hanya dalam kegiatan formal namun juga dalam pertemuan informal. Sehingga pada akhirnya aplikasi LENS dapat digunakan oleh semua pihak yang menjadi target penggunanya dengan baik.

Selain kepemimpinan yang memiliki komitmen kuat dan dukungan SDM yang solid, proses transformasi sistem digital assurance di jurusan Sastra Inggris juga didukung oleh ekosistem organisasi yang baik. Jurusan Sastra Inggris termasuk dalam kategori jurusan kecil secara kuantitas, baik dari sisi mahasiswa maupun dosen. Walaupun kecil namun kualitas komunikasi antar individu di dalamnya terjalin dengan baik. Pola hubungan komunikasi vertikal dan horizontal di dalamnya terbangun dengan baik. Hal ini menjadi salah satu faktor yang mendukung mudahnya proses implementasi aplikasi LENS dan konteks transformasi digital assurance. Tanpa pola komunikasi yang baik, visi dan misi ketua jurusan yang diterjemahkan dalam bentuk kebijakan dan program tidak akan mendapat dukungan dari anggota organisasi. Hambatan-hambatan yang umum terjadi dalam sosialisasi produk digital baru pada generasi yang lebih tua dapat diatasi dengan pola komunikasi yang baik.

Pola transformasi yang digunakan adalah Top-Down. Terlihat dari inisiasi kegiatan yang berasal dari ketua jurusan dan sekretaris jurusan. Kegiatan ini merupakan implementasi dari visi dan misi jurusan. Walaupun visi dan misi disusun secara bersama, namun dalam implementasi berbentuk kebijakan dan program disusun oleh ketua dan sekretaris jurusan. Perubahan organisasi dapat terjadi melalui mekanisme top down maupun bottom up. Perubahan top down, didorong oleh level atas, untuk kepentingan strategis organisasi. Biasanya perubahan yang bersifat top down akan terjadi dalam waktu yang lebih cepat dan bersifat lebih komprehensif dibanding dengan perubahan yang bersifat bottom up. Perubahan bottom up adalah perubahan yang di dorong dari level bawah menuju ke atas. Biasanya perubahan ini didukung oleh manajemen level bawah dan menengah sebagai agen perubahan. Perubahan bottom up dapat dilihat pada inovasi teknologi maupun perbaikan prosedur kerja, di mana idenya berasal dari karyawan level bawah yang berada di lapangan dan melihat perlunya dilakukan perubahan untuk perbaikan organisasi.

Perubahan dengan pola top down membutuhkan dukungan yang kuat dari SDM dan ekosistem organisasi. Hambatan utama perubahan umumnya berasal dari resistensi SDM terhadap hal baru yang 
dianggap akan mengganggu ekosistem dan budaya organisasi yang sudah mapan. Namun hambatan ini dapat diatasi jika pola komunikasi dan budaya organisasi sudah terbentuk dengan baik antara pimpinan dan seluruh anggota organisasi (Suci, 2017). Hal ini terlihat pada perubahan yang terjadi di jurusan Sastra Inggris yang mampu mentransformasi sistem quality assurance manual menjadi digital assurance yang melibatkan seluruh dosen dan mahasiswa.

\section{KESIMPULAN}

Berdasarkan pemaparan diatas, disimpulkan bahwa pola transformasi yang terjadi dalam proses implementasi digital assurance di jurusan Sastra Inggris adalah Top-Down. Proses transformasi Digital Assurance di Jurusan Sastra Inggris didukung oleh faktor leadership dan komitmen yang kuat, dukungan SDM yang memadai dan ekosistem organisasi yang kondusif.

\section{Daftar Pustaka}

Adina, B. L. (2007). Teaching Emotional Intelligence, Strategies and Activities for Helping Student make Effective Choices. California: Corwin Press.

Basuki, A., \& Basuki, A. (2004). Implementasi Sistem Jaminan Mutu (Quality Assurance) Proses Pembelajaran di Perguruan Tinggi. Jurnal Penelitian Dan Evaluasi Pendidikan, 6(1). http://doi.org/10.21831/pep.v6i1.2042

Cecep, A. (2011). Strategi Peningkatan Mutu Pendidikan Di Perguruan Tinggi. Jurnal Sosioteknologi, 10(24), 1184-1190.

Eko Supriyanto. (2012). Model Penjaminan Mutu Pembelajaran Pada Perguruan Tinggi Swasta. Jurnal VARIDIKA, 24(4).

http://doi.org/https://doi.org/10.23917/v aridika.v24i4.698
Fitrah, M., Ruslan, \& Hendra. (2018). Urgensi Sistem Penjaminan Mutu Internal Terhadap Peningkatan Mutu Perguruan Tinggi. Jurnal Penjaminan Mutu, 4(1), 76. http://doi.org/10.25078/jpm.v4i1.400

Indarti, L. (2017). Dimensi-dimensi Kepemimpinan Transformatif Pendidikan Islam. Ta'allum: Jurnal Pendidikan Islam, 5(1), 21-36. http://doi.org/10.21274/taalum.2017.5.1 $.21-36$

Mark Olssen. (2004). Education Policy: Globalization, Citizenship and Democracy. London: Sage Publications.

Ngurah Triyana, I. G. (2017). Penjaminan Mutu Pendidikan Melalui Teknologi Informasi di Institut Hindu Dharma Negeri Denpasar. Jurnal Penjaminan Mutu, 3(1), 119. http://doi.org/10.25078/jpm.v3i1.98

Nuraeni, Y. (2012). Perancangan Sistem Informasi Penjaminan Mutu Perguruan Tinggi Bidang Sumber Daya Manusia. Jurnal Sistem Informasi, 6(1), 32. http://doi.org/10.21609/jsi.v6i1.276

RISTEKDIKTI. (2016). Sistem Penjaminan Mutu Perguruan Tinggi. Jakarta: Direktorat Jenderal Pendidikan Tinggi.

Suci, A. (2017). Penjaminan Mutu Perguruan Tinggi: Dilema Politik Organisasi dan Urgensi Penggunaan Profesional Eksternal. Jurnal Penjaminan Mutu, 3(2), 215. http://doi.org/10.25078/jpm.v3i2.202

Sulaiman, A., \& Wibowo, U. B. (2016). Implementasi Sistem Penjaminan Mutu Internal Sebagai Upaya Meningkatkan Mutu Pendidikan Di Universitas Gadjah Mada. Jurnal Akuntabilitas Manajemen Pendidikan, 4(1), 17. http://doi.org/10.21831/amp.v4i1.8197 
Syafnan. (2016). Kepemimpinan Transformatif di Lembaga Pendidikan. Ta'dib, 13(1). Retrieved from http://ecampus.iainbatusangkar.ac.id/ojs /index.php/takdib/article/view/177

Tsui, C. C. (2002). Quality in Higher Education: Policies and Practices.A Hongkong Perspective Introduction and research Approach.

Willar, D., Linton, J., Kaparang, R., \& Kaparang, R. (2015). Identifikasi Profil Budaya Organisasi Yang Mendukung Implementasi Sistem Penjaminan Mutu Perguruan Tinggi. Jurnal Cakrawala Pendidikan, 2(2). http://doi.org/10.21831/cp.v2i2.4824 